\title{
The Historical Development of the Ancient Egyptian Autobiographies ${ }^{1}$ \\ Mohammed Heragi Ahmed Sayed \\ PhD candidate- Minia University
}

\begin{abstract}
:
This essay discusses the genre of the ancient Egyptian autobiographies and it proposes that the historical events played an important role in developing the autobiographies.

The researcher followed the analysis methodology. The analysis builds up in detail, answering how and why the autobiographies developed, leading at the end to the final conclusion.
\end{abstract}

\section{Discussion:}

One of the oldest and most enduring elements of the ancient Egyptian mortuary tradition was the self-presentation by the deceased to the new generations who might pass by. Scholars are not agreeing on just how to designate these self-presentations. Are they biographies, autobiographies, "biographical" or "autobiographical" narratives? Autobiographies are well attested than biographies, although the texts that Egyptologists term autobiographies may not correspond to the Western expectation of literary works in which people give accounts of their lives. ${ }^{2}$

There are two kinds of material in the autobiographies. One type is simply descriptive and focuses on the self-portrait that the owner wishes to present. The second type of material consists of narrative passages in the form of continuous text that relates in chronological order of the owner's career, or at least its principal stages. ${ }^{3}$

The Egyptian autobiographies were mortuary writings and were always the presentation of the deceased to posterity within the funerary context. They appeared in inscriptions, either in the tomb chapel or on a separated stela which may appeared in the tomb, and a temple. Later, Statues inscribed with autobiographies as well and rarely appeared on the sarcophagi such as Sarcophagus-lid inscription of Wennofer during the Ptelomaic period. ${ }^{4}$

Most of the autobiographies were in the first-person singular pronoun. Their intended was the new generations who will visit or pass by the tomb or the monument. Particularly, those who can read so that, the content of the autobiography was really aimed to the elite. The purpose of the autobiography was to persuade the visitor to enter a tomb in a suitable state of purity and to read an offering prayer on behalf of the deceased, but their meaning was wider. They were also closely associated with prestige. By praising the deceased's qualities, they persuade the visitor to recite the prayer. ${ }^{5}$

The autobiography had a connection with the next life so, the text was quite selective in preserving the desired image of the individual. ${ }^{6}$ Its focus was the successful course of the person's career, with a strong emphasis on his moral worthiness. Moreover, the genre was restricted to the non-royal realm as the king represent the whole nation in sacred manner and the kingship was more cosmic and too ceremonially to lend itself to private narrative expression. ${ }^{7}$ 
The earliest autobiography appeared in the early $4^{\text {th }}$ Dynasty by the Nomarch Methen, ${ }^{8}$ from Saqqara his autobiography was defined by its report of service and reward for service to the state or the king. It was reflective of the early career autobiographies that stress state service and which did not yet contain explicit expressions of moral values, while the tomb inscription of the priest $\boldsymbol{W r}-\mathbf{H w} \boldsymbol{w}$ from Giza was the earliest statements of self-presentation with moral worthiness, occurred near the end of the $5^{\text {th }}$ Dynasty: ${ }^{9}$

$$
\begin{gathered}
\operatorname{pr}(. i) \mathrm{m} \text { niwt(.i) hA.n(.i) m spAt(.i) Dd.n(.i) mAat im ir.n(.i) mAat im } \\
\mathrm{n} \text { sp di(.i) sDr s nb Spt ir(.i) Hr xt nb Dr mswt(.i) } \\
\text { Mry it.f mry mwt.f } \\
\text { imAxw xr ntyw Hna.f bnr xr snw.f } \\
\text { mry n bAkw.f imAxw xr ntyw Hna.f } \\
\text { xp(.i) Hr wAt nfrt nt imnt xppt imAxw xr.s }
\end{gathered}
$$

I have come from my town and have descended from my nome,

I have spoken Maat (Truth) there, having done Maat there.

I never let a man spend the night angry with me about something, since I was born.

One beloved of his father, praised of his mother

Worthy before those who were with him Kind to his sisters and brothers

Beloved of his servants. One honored before those who were with him

I traveled on the good road of the West upon which the honor one travels. ${ }^{10}$

The basis of the tomb owner's life was Maat. It was the most important concept in the ancient Egyptian thought embodying correct conduct in the world and in man's relations with people, the king, and the gods. The two main themes of the autobiography: a man's career and his moral self-presentation stemmed directly from the tomb owner's position in life. ${ }^{11}$ According to Jan Assmann, "the genre of the autobiography was developed from two different sources: (a) from the names and titles of the tomb-owner, which were expanded into a narrative of his career; and (b) from a commentary on the tomb and its sacrosanct nature, which were developed into declarations of the owner's moral integrity." 12

The ancient Egyptian autobiography did reveal signs of change and development in the tombs next to Memphis, where the royal court was located. Its first appearance was in the $4^{\text {th }}$ Dynasty where, the tomb owner described how the tomb was built and the titles he gained during his life. During the $5^{\text {th }}$ and $6^{\text {th }}$ dynasties evolved the fuller versions genre of self-presentation by narration and declaration. They recorded the tomb-owners' self- evaluations in which they assert to have fulfilled their moral obligations towards the society such as take care of the lower social groups "giving bread to the hungry, clothes to the naked" such these declarations were recorded in tomb after tomb . By the $6^{\text {th }}$ dynasty, a few autobiographies appeared outside of Memphis, such as Elephantine, Edfu, Abydos, Deshasheh, ${ }^{13}$ and Dayr al-Gabrawi. ${ }^{14}$

In this period, it was the officials of the court, who had the means to build tombs for themselves. They had a warrant from the king, and therefore the ability of achieving the king's wishes and ensuring the royal praise and appreciation in their autobiographies. Examples of such officials include viziers, courtiers, governors of 
the provinces, and high priests. The king is the unchallenged focus of attention, and even the other gods receive short notice.

By end of the Old Kingdom, the autobiographies include three topics; the major events in the tomb owner's career, a moral self-presentation, and the prayerful speeches which is "the offering formula, the appeal to the living, and the warning to visitors." These three areas correspond to ideas of self-esteem, interconnectedness, and recognition that the world was governed by an ideal of justice maat.

An example for the Old Kingdom autobiographies, a tomb inscription of $\mathbf{N f r}$ $\boldsymbol{s S \boldsymbol { m }}$-pth, $\mathbf{6}^{\text {th }}$ dynasty at Saqqara, On the right side of the façade: ${ }^{15}$

[pr.n(.i) m niwt(.i)] [hA.n(.i) m spAt(.i)]

[ir.n(.i)] mAat n nb.s sHtp.n(.i) sw m mrrt.f

$\operatorname{Dd} . n(. i) n f r w H m(. i) n f r$ [iT.n(.i) tp-nfr]

[mr(.i) nfr im] n rmT wp.n(.i) snnw r Htp.sn

nHm.n(.i) mAr m-a wsr r.f m sxmt.n(.i) im

[Dd.n(.i) mAa ir.n(.i) mAa]

[rdi.n(.i) t n Hqr] Hbs n HAy s smA(.i) tA m iwi

qrs.n(.i) iwty sA.f ir.n(.i) Xn [n iwty Xnt.f]

[sm.n(.i)] nmHw n sp Dd(.i) xt nb Dw r rmT nb n sxm-irf

[I have gone from my town,] [I have descended from my nome,]

[having done] justice(Maat) for its lord, having contented him with what

he loves. I spoke the good, I repeated the good,

[I grasped the right manner,] [for I wanted the good] for people.

I judged two parties so as to content them,

I saved the weak from one stronger than he as best I could,

[I spoke truly, I acted justly.]

[I gave bread to the hungry,] clothes to the naked,

I landed one who was stranded, I buried him who lacked a son,

I made a boat [for the boatless,] [and supported] the orphan.

I never spoke evil against anyone to a potentate.

In the First Intermediate Period, the political scene changed, the central monarchy lost its hold on authority and the power shifted to provincial centers. The individual nomes became self-governing, all sections of the population, the rich, the poor, the rising middle class, could erect tombs and memorial stones with selfpresentations designed to secure a share in immortality." And undergirding this quest for immortality was the living with Maat life. A royal warrant was no longer necessary. Autobiographical texts of the ruling authorities in this period focus on how the individual provides order, food, or protection in an age of chaos. Lesser officials describe their political and economic successes as the result of their own labor, or at times the result of some assistance from the town gods, but not as the benefaction of pharaoh. The king is no longer the center of all value. The nomarch Henqu from Deir El-Gebrawi, the $12^{\text {th }}$ nome of Upper Egypt, depicts himself as a savior who able to protect his dependents from disaster and assure their good future: ${ }^{16}$ 
ink i imAxw mrii $n$ itw Hsii $n$ mwwt qrsw $n$ iAww wHa nmHw.Tn n qAs itH.Tn tp mr mk iAw.Tn m [sH] n srw n sp bAk sAt nt waim.Tn an[an.s n?]... aw.s r.i $\mathrm{n}$ rdi.i $\mathrm{mDw}(\mathrm{t}) \mathrm{m}$ wa... $\mathrm{n}$... $\mathrm{m}$ bw pn nti wi im iw rdi.n(.i) t Hnqt n Hqr nb n U.E. 12 Hbs n HAii im.s

[snt.f]n sp kfii(.i) s Hr Xrt.f iw.f w(i) Hr.s n nTr niwti ink Dd wHm bw nfr

n sp hm(.i) s n wsr r.f siw.f Hr.s n nTr aHa.n(.i) Hm

ink i gr mrii $n$ it.fh Hsii $n$ mwt.f imi $n$ sn.f imA imi n

I was an honoured one, beloved of the fathers and praised of the mothers, one who is the burier of the old ones,

who released your orphans from the towing rope, which you dragged above the canal

Behold, you grew old in the council of magistrates.

Never had a daughter of one among you been enslaved, so that [she might complain to] ... her arms against me. I did not put fetters on any man

[for I wished it should go well with me] in this place in which I am.

I gave bread and beer to every hungry man of U.E. 12,

and clothes to the naked one in it.

Never had I deprived a man of his possessions that he would complain of me about it to the local god. I am one who spoke and reported fairly.

Never had I slandered a man to one who was more powerful than he that he would complain about it to the god

I was also one beloved of his father, praised of his mother, well-mannered to his brother and kind [to his sister].

Henqu begins his self-presentation by declaring not simply that "he is loved and praised by his own mother and father", but rather "I am one worthy, beloved of fathers praised of mothers." This love and praise are based on the fact that he: "released your youths from the towrope .. . no daughter of yours was made to work by coercion" nor was "her arms pressed against me" and "I did not put fetters on any man." This he did to rebuild moral community after disruption. that he "spoke and repeated the Good" and was beloved and praised by his family as well as "excellent of character" to them. ${ }^{17}$

The women of ancient Egypt enjoyed full equality with men. True is that their social and legal status was much above that of women elsewhere in the ancient world. During The Old Kingdom, the burials of highborn ladies included the same funerary prayers that had been formulated for men : requests for offerings and a good burial in the west, and the freedom to travel the good ways of the west and to ascend to the "great god". Besides some certain ritual functions in the temples, ladies did not hold public office. Nor did they relate events of their lives in 
autobiographical tomb inscriptions, the $1^{\text {st }}$ Intermediate Period brought an advance in the display of selfhood. The cemetery of Naga el-Deir, the $8^{\text {th }}$ nome of Upper Egypt, so rich in modest tombs and stelae of the rising middle class, yielded a goodly number of grave stelae of women, which had shown women not in the company of their husbands but alone, ${ }^{18}$ such as the Stela of Neni the high priestess of Hathor from Naga el-Deir: ${ }^{19}$

\section{imAxwt xr nTrw Tinw, Hsyt hAy.s imyt-wrt aA nt nfr qd}

\section{For the one honored before the gods of thinis, The praised one of her husband The great priestess of excellent character}

Self-presentations of the $1^{\text {st }}$ Intermediate Period showed the basic meanings of Maat, the same as they were in the $6^{\text {th }}$ Dynasty. What has been added was a great advance in thinking about experiences and formulating conclusions. The ability to perform the works of Maat was then seen as a background for the character, the description of one's perfect character became integrated with the career narration, so that the distinction between the two aspects of autobiography was effaced like the high priestess Neni she described her career as "The great priestess" with "excellent character". At that time, it was love of the people by the Maat behavior that caused memory of him to endure. The Stela of the Ruler Indi in Metropolitan Museum 25.2.3 from Naga el-Deir tends to link his claim of being an excellent citizen with his being one loved by his parents and siblings: ${ }^{20}$

Dd ink nDs iqr n rA-a xt smAy n Had ink mry n it.f Hsy n mwt.f mrrw snw.f

I am a citizen excellent in battle, A companion to his crew,

I am (one) beloved of his father, praised of his mother,

Whom his brothers and sisters love. ${ }^{21}$

Thus, public service is informed by the concept of leadership as a moral vocation. Each person seeks to establish in his declaration of virtues evidence of his worthiness as both a person and public servant. Later in the Middle Kingdom, Rediu-khnum describes both his moral and professional excellence as an integrated whole. ${ }^{22}$

In the Middle Kingdom the central monarchy was reestablished, and the biographies also reflect the changes in social temperament brought on by the historical incidents. Even more people than before, of more classes, began to express themselves in this genre and the content became fuller. Interestingly, the majority of autobiographical texts of the Middle Kingdom could be found in the provinces, rather than the capital. From Elephantine to Beni Hasan, passing by Asyut, the necropolises contain numerous inscriptions evoking the characters of local potentates, even in regions of expedition near the quarries; there are many inscriptions at Hatnub and Wadi Hammamat. ${ }^{23}$ 
In the Middle Kingdom, the king once again held a central role in the selfpresentation. The individual emphasizes his loyalty to the king as before, but now with a sense of possibility of a reward for personal achievements as well, a sense that one could create his own success in life, even from humble origins. This concept of human possibility was reflected in the concept of "iqr" which contains a wide range of meanings: excellence, worthiness, superiority, perfection, wealth, achievement and virtue. ${ }^{24}$

As early as, the $11^{\text {th }}$ Dynasty was the beginning of the inner-directedness, the ancient Egyptian discovered in himself four sources of selfhood action: his heart, his belly, his character and his nature, the forces that raised, shaped, and channeled man's thoughts, desires, inclinations, and actions, including his understanding of right and wrong. ${ }^{25}$

Firstly, his heart "ib, HAty" Key to the responsible exercise of freewill was moral conscience, In the history of self-presentation, the notion of the "heart" appeared only in the Middle Kingdom ${ }^{26}$. Before that during the Old Kingdom, there was no explicit mention of the heart. The individual was seeing himself as the executive organ of the royal will. The heart of the king think and plan for all.

Rediu-khnum of Dendera, a servant of queen Nefrukayit during Middle Kingdom, in his stela CG $20543^{27}$, he said:

$$
\text { in ib(.i) sxnt st(.i) in qd(.i) rdi wAH(.i) HAt }
$$

It was my heart that advanced my rank, It was my character that kept me in front.

Secondly, his belly/body (Xt), harbored appetites, desires and passions, and thus often produced greed and lust. But "the belly" was also used as a synonym for "the heart" in the positive sense of "thought. Amenemhet, nomarch of the Oryx nome In the reign of Senusert I, in his tomb at Beni Hasan, recorded a brief statements, phrased in the third person. as epithets in a non-narrative context ${ }^{28}$ :

nn wn Hnt m Xt.f Dd.f m mdt mAat

No greed is in his body, what he speaks is truth.

Thirdly, his character ( $q d, b i A t, x p r w)$, they meant just what we mean by the character: the engraved and matured form of the personality. The Egyptians also assumed other definitions of the good in this point. The good included good character and kindness. Good character will be remembered in the future, while evil men are forgotten. Good character was even more important than good deeds. On the stela BM 159 of The chief priest Rwd-aHAw, Abydos, Middle Kingdom, it has a brief characterisation of the "good man" (line 12): ${ }^{29}$ 
ink ir qd.f mrrt rmT m Xrt-hrw nt ra nb

I am one who made his character, one beloved of people each day.

Finally his nature (iwn, irw, sxr, biAt).the best assertion for the role of the good nature as inner-directedness of the individual, the minor priest and farmer at Abydos Mentuhotp ${ }^{30}$; he was orphaned early, and entirely guided and taught by his own good nature, his strongest claim refers to the primacy of "nature" over "nurture. In this point, the Egyptian had made the fundamental discovery that he possessed "innate" qualities:

qb Ssp $t$ r tr.f idn.n n.f sxr.f mwt m xnt it Hr ir gm.k sA.i nfr qd sbA.n biAt.f mi Xrd xpr m-a it iw sk.(w)i grt wA.kwi r $\mathbf{n m H}$

"A cool one, who receive bread on time, whose conduct replaced him a mother at home. a father who said. "Take note, my son. One well disposed and taught by his nature, like a child grown up with a father, but behold, I had become an orphan!

The Middle kingdom time of the self-laudation, the innovation of the phrases developed more than the $1^{\text {st }}$ intermediate period. A new feature in the new style was using the metaphors to describe the one's perfect character, such as Rediukhnum describes himself as "a precious staff made by God" (xt Sps ir.n nTr) reflected his excellence, in planning and nobility of performance. ${ }^{31}$

Also during the Middle Kingdom started an innovation in phrases with many $i b$ - epithets describing the individual such as Joy, Kind, gracious, Magnanimous, Greedy, Rapacity, upright, straightforward, heedful joyful skilled hale of heart not arrogant considerate right minded, truthful, devoted, excellence trusty, trust gladness, joy, modest, sorrow, forceful, heart's desire i.e. pleasing, not violent. ${ }^{32}$

The New kingdom began, it was time that the greatest number of biographies were produced. Most of the tomb texts are concentrated on the West Bank at Thebes, where their number in the dozens, as a result of the prosperity and importance of the city, while temple monuments with autobiographical inscriptions especially statues appeared throughout the country. ${ }^{33}$

The New kingdom remarked by the appearance of gods in the private tombs and stelae in other words, personal piety. Men and women were depicted worshipping the gods, and in the texts the gods were invoked more directly and more frequently than had been done before with replacing maat "the will of society" by "the will of god". The used expressions of that time were "di nTr m $i b . f$ " and "ir Hr mw.f": "to place god into one's heart" and "to act in his water" meaning to act in a way which was loyal and faithful to his will. These expressions make their first appearance in the reign of Hatshepsut and Thutmosis III. Paheri who served under both Thutrnose I and Hatshepsut, on a great stela in his tomb at EL-Kab, he is describing the afterlife for the righteous. He says of life in the beyond: ${ }^{34}$ 


\author{
rs.k nfr m Xrt Dr n.k sDb nb r tA \\ sb.k nHH m nDm-ib. m Hswt nTr imy.k
}

You wake gladly every day, all afflictions are removed. . . You cross eternity in joy, in the favor of God which is in you. ${ }^{35}$

Paheri ends with his description "You cross eternity in joy, in the favor of God which is in you " reflects the new concepts in the New Kingdom describing the heart as "a god in everybody." or "your God is your Heart" This reference to "divine being" or "divine presence". The heart here played a central role in moral development and guidance. One was blessed by his guidance to good behavior and it would bear witness in vindication of a person on the Day of Judgment.

As for the $18^{\text {th }}$ Dynasty, "silence" became part of the self-presentation, the silent one refered to the sage, The silent man was patient, modest, calm, up to a point self-effacing, but above all master of himself under all circumstances, and silence was a sign not of humility but of superiority. Son of the mayor of Thebes in the reign of Amenhotep I, called Nufer, speaks of himself at Deir el-Bahri ${ }^{36}$ : Ink grw mAa $\mathrm{n}$ Xt mwt.f nHi bw nbw m qdt.f I am one truly silent from the womb of his mother, Whom everyone wishes to emulate. $^{37}$

The concept of Maat always has been the protection of the weak (to feed the hungry, clothe the naked, to ferry the ship-less, to the heirless, to shelter the widow and the orphan etc.). It was transferred to the man-god-relationship, putting god in the position of a protector "the good shepherd" and man in the position of the poor and the weak. ${ }^{38}$

Several Ramesside texts point out that there was no protector among men but the deity Amun, Mut, etc - were the protectors on which a human heart can rely, the autobiographical statements were integrated with hymns to the gods in such a way that the self-presentations were linked to prayerful requests for a benign reception in the hereafter. ${ }^{39}$

The concept of sin with respect to god developed to be the most innovative aspect of the Ramesside time, man was capable of guilt towards god and, god knew everything and he will distribute his favor or disgrace in strict according to human attitude and behavior. For example $\boldsymbol{n f r}-\boldsymbol{a b} \boldsymbol{w}$ narrates his personal guilt well-known as hymn to Ptah, from Dier El-madina BM 589, he expressing how he swore a false oath to Ptah, whereupon the god caused him 'to see darkness by day, and he ended with a warning that it is dangerous to offend Ptah in this way: ${ }^{40}$ 


\author{
Dd.f ink $\mathrm{s}$ arq $\mathrm{m}$ aDA $\mathrm{n} \mathrm{ptH} \mathrm{nb} \mathrm{mAat}$ \\ di.f ptr.i kkw $m$ hrw \\ iw $r$ Dd bAw.f n xm sw rx sw n Sri aA \\ sAw tn $\mathrm{r} \mathrm{ptH} \mathrm{nb} \mathrm{mAat}$
}

I am a man who swore falsely by ptah, lord of maat,

And he made me see darkness by day.

Will declare his might to the fool and the wise,

To the little and great: Beware of ptah, lord of maat! ${ }^{41}$

With the end of the New Kingdom and the beginning of the $3^{\text {rd }}$ intermediate Period (1069-664 BC), the government authority once again under regional lords, then the Late Period (664-332 BC) ${ }^{42}$ with a succession of foreign dynasties divided by periods of native control. After seven centuries (332 BC), ancient Egypt was no longer an independent kingdom, as the country fell to Greek and then Roman control.

From the End of the New Kingdom to the Roman takeover, about a thousand years. The extant biographies continue to develop and change in this era, although before the Ptolemaic period few appeared in the tomb funerary chapels, perhaps because it had become too costly to have them built. Karnak Memphis, Sais, and the Serapeum (Saqqara) among others as places that supply a large number of Late Period autobiographies. Most were inscribed on statues in this time, except at the Serapeum, where stelae continued to be the favored form. ${ }^{43}$

The prominent features of the literature of this period, can be observed through the autobiographies of the high officials, the princes, and the priests, such as the governance priests of Amun at Thebes Djedkhonsefankh, Nebneteru who served Libyan kings of the Twenty-second Dynasty, while Harwa, and Montemhet held office under the Twenty-fifth (Nubian) Dynasty. The Saite renaissance (664$525 \mathrm{BC})^{44}$ was reflected on the Ibi's autobiography, which represented the peak of the archaizing renaissance as his text thus reads like a text of the $6^{\text {th }}$ Dynasty. The destruction of the Saite Dynasty through the Persian conquest (525 BC) of Egypt is reflected in the biography of Udjahorresne, who try to restore a normal life through cooperated with the Persian conquerors after they had settled down to rule. The career of Somtutefnakht extended three eras: the final years of Egyptian independence under the Thirtieth Dynasty, the brief second Persian domination, and the destruction of the Persian Empire by Alexander the Great. Petosiris, the high priest of Thoth at Hermopolis Magna, looked back on long years of service to his town in the last decades of the fourth century, when Persian dominion ended and Macedonian rule was installed. ${ }^{45}$

By that time, the form of the autobiography had undergone, the appeal to the reader comes forward in the text so that the entire work was a direct address. The request at the end for the offering is often lacking; instead the subject of the text 
wanted the reader to take the deceased's life as an example and recite his name. The language used is mostly still Middle Egyptian, just as in the older texts, with an occasional example of Late Egyptian only during the $22^{\text {nd }}$ and $23^{\text {rd }}$ Dynasties after that, the texts were written in the Middle Egyptian. ${ }^{46}$

Personal piety was a strong theme in the later autobiographies that the individual spoke directly to the gods, not merely to the reader or the local priests. In the previous periods a good deed automatically led to an appropriate outcome, whereas in that period, God is the personal mediator of each result and acts according to the divine will, in a way that cannot be predicted with certainty. ${ }^{47}$

The Late Period autobiographies in general turn the focus of the main content from the netherworld to the present life and seeks fulfillment in the fame of one's good name, good deeds, and more importantly, one's offspring. Once death becomes the end of life, the idea of the judgment of the dead generally withdraw, as the belief in the afterlife became uncertain, immortality is possible through memory means; children and the good reputation. ${ }^{48}$

Through the events, and the historical situation, which effected in the ancient Egyptian thoughts and reflected in literature led to a new theme of autobiographies flourished during the Ptolemaic Period with unusual new concepts of "laments" in the cases of sudden death for young people. The new concepts looked to the underworld as a dark place with no mercy for children like Thothrekh Son of Petosiris and the girl Isenkhebe Autobiographies or young ladies such as the Stela of $\mathbf{T a}$-imhotep, ${ }^{49}$ even for men such as the childless man Padi-sobek Stela. ${ }^{50}$

As a whole, many of the later autobiographies continue in the tradition of the past, but some was different, the intense focus on the gods instead of the king, the turning towards family and the inner circle rather than one's participation in the world at large, a sense that there is no reliable pattern of deed and consequence in life which further heightens the dependence on the gods, and the outright declaration that the afterlife is empty. ${ }^{51}$ The loss of confidence in the afterlife is best seen through self-lamentation autobiographies of the young lady Ta-imhotep, the children Thothrekh and Isenkhebe and a childless man Padi-sobek.

\section{Conclusion:}

The autobiographies developed frequently through all the ancient Egyptian periods. It was never one content but a continuous change according to the historical events which reflected the image of the Egyptian society through different periods.

The historical incidents effected in the self-presentation of the individuals deeply, stable and strong periods led to optimism like the Middle kingdom autobiographies with their innovation of language and remarkable metaphors, While intermediate and occupation periods led to pessimistic view even for faith of the next life which clear in the self -lamentation of the Ptolemaic period autobiographies. 
1 This essay is a part of a $\mathrm{PhD}$ thesis in progress entitled "Self-Lamentation in Ancient Egyptian Autobiographies during Ptolemaic Period" submitted for Tourist Guidance Department, Minia university, under Supervision of; Prof. Dr. Mansour El-Noubi Professor of Egyptology, South-Valley University, Dr. Samar Mustafa Kamal Associated professor of Tourist guidance, Minia University and, Dr. Ahmed Abo El-Maged Associated professor of Tourist guidance, Minia university.

2 Gunn J. V.(1910), “Autobiography” in: Hastings, J. (ed.), the encyclopedia of religion and ethics, Vol. II, Edinburgh: T. \&T. Clark, pp.7-11.

3 Perdu, O.(1995), "Ancient Egyptian Autobiographies," in Jack M. Sasson (ed.), Civilizations of the Ancient Near East, Vol. IV, New York: Charles Scribner's Sons, P. 2243.

4 Lichtheim, M.(1980), Ancient Egyptian Literature, Volume III: the Late Period, Berkeley, Los Angeles: University of California Press, pp.54-58.

5 Baines J.(1991), "Society, Morality, and Religious Practice," in Byron E. Shafer (ed.), Religion in Ancient Egypt: Gods, Myths, and Personal Practice, Ithaca, New York: Cornell University Press, P.140.

6 Guksch H.(1994), Königsdienst: Zur Selbstdarstellung der Beamten in der 18 Dynastie, Studien zur Archäologie und Geschichte Altägyptens 11, Heidelberg, pp.1-2.

7 Lichtheim, M.(1988), Ancient Egyptian autobiographies chiefly of the Middle Kingdom, Orbis Biblicus et Orientalis 84, Fribourg, p.5.

8 Baines, J. (1999), "Forerunners of Narrative Biographies" in A. Leahy and J. Tait (eds)

Studies on Ancient Egypt in Honour of H. S. Smith, London, pp.29-31; Thomas S.(2003), Senfru: the pyramid builder, pp.66-68.

9 Sethe, K.(1932), Urkunden des Alten Reiches I, Leipzig, p.57; Lichtheim M.(1992), Maat in Egyptian autobiographies and related studies, Orbis Biblicus et Orientalis 120, Fribourg, p.9

10 Karenga, M.(2004), Maat the moral ideal in ancient Egypt, New York, p.280.

11 Lichtheim, Ancient Egyptian autobiographies, pp.5-6.

12 Assmann, J.(2005), "axial "breakthroughs" in ancient Egypt" in Arnason, J. P.( ed.), Axial Civilizations and World History, Brill, p.140.

13 Kanawati, N. (1993), Deshasha, The Tombs of Inti, Shedu and Others: The Australian Centre for Egyptology Reports 5, Sydney: The Australian Centre for Egyptology, pp.11-15.

14 Kanawati N.( 2005), Deir el Gebrawi I, The Australian Centre for Egyptology reports 23, Oxford: Aris and Phillips Ltd, pp.11-20.

15 Edel, E. (1981), Inschriften des Alten Reichs, Westdeutsher, p.77-85; Urk I,199.1 ; Lichtheim, Maat in Egyptian autobiographies, No.8, pp.13-14.

16 Urk. I, 76-79.; Kanawati N.( 2005), Deir el Gebrawi I, pp.71-73, pls. 29-30,57, 66-67.

17 Karenga, Maat the moral ideal, p.103.

18 Lichtheim, Ancient Egyptian autobiographies, p.37.

19 Dunham, D.(1937), Naga-ed-Dâr Stelae of the First Intermediate Period, Boston, No.53, pp.65-66, pl.16,1.

20 Dunham, Naga-ed-Dâr, No.78, pp.92-94, pl.28.2.

21 Hayes, W.(1953), The Scepter of Egypt I, New York, pp.139-141.

22 Lichtheim, Ancient Egyptian autobiographies, p.42.

23 Perdu, autobiographies, IV.2249

24 Lichtheim, M. (1996), "Didactic literature", in: A. Loprieno, (ed.), Ancient Egyptian literature, History and Forms, Leiden, p.257.

25 Ibid, p.258. 
26 Assmann says "This does not mean that the heart notion may have not occurred much earlier in other genres. The Pyramid Texts contain many references to the "heart", but these belong to a historical "deep structure" of the idea. More important, in this respect, are two other sources: proper names and literary "wisdom" texts. If the name $\mathbf{H q A} \mathbf{A}$-ib (that is, "ruler of (one's own) heart" or "(My) heart is (my) ruler"), which appears in the 6th dynasty, can be really said to express the notions of self-control and of "heartdirectedness", then it has to be regarded as a precursor of ideas which become prominent in autobiographies only in the Middle Kingdom. The other "problem" case is a literary text, the "Teachings of Ptahhotep", a text of 5th dynasty, where the idea of self-control (xrp-ib: "submerging the heart") plays a great role. However, the question of whether this indication is to be taken literally or, rather, to be regarded as a literary fiction remains controversial. Assman`s reconstruction of the history of the heart in ancient Egypt rests upon the assumption that the Teachings of Ptahhotep, or at least the pertinent sections, belong to the Middle Kingdom". see Assmann, "breakthroughs in ancient Egypt" p.140.

27 Lange, H.O. and Schäfer, H.(1908), Grab-und Denksteine des Mittleren Reiches im Museum von Kairo II, Berlin, p.166.

28 Sethe, K. (1935), Historisch-biographische Urkunden des Mittleren Reiches, Abteilung VII, Leipzig, p.18.

29 Faulkner, R. O.(1951), The Stela of Rudj'ahau, in JEA 37, p.48, Fig.1.

30 Petrie, Fl.(1925), Tombs of the Courtiers and Oxyrhynkhos, London, p.19 (Gardiner's transl.), pls.22-23

31 Karenga, M.(2004), Maat the moral ideal in ancient Egypt, New York, pp.65-66

32 Lichtheim, Maat in Egyptian autobiographies, pp.145-146.

33 Perdu, “Ancient Egyptian Autobiographies,” IV:2251.

34 Urk IV, 117.9-12; Lichtheim, Maat in Egyptian autobiographies No.45, p.49.

35 Karenga, Maat, the moral ideal, p.85.

36 Edwards E.S.(1965), Lord Dufferin's Excavations at Deir El-Bahri and the Clandeboye Collectionin" in JEA 51, p.25, pl.11.2.

37 Lichtheim, M. (1997), Moral Values in Ancient Egypt, OBO 155, Fribourg, pp.52-53

38 Assmann, J. (2002), The Mind of Egypt: History and Meaning in the Time of the Pharaohs, New York: Metropolitan Books, p.136

39 Assman. J.( 1995), Egyptian solar religion in the new kingdom, , London \& new York, pp.73-74.

40 Erman, A.(1911), Denksteine aus der thebanischen Gräberstadt, Berlin, pp.1101-02.

41 Gunn, B. (1916), "the religion of the poor in Ancient Egypt", in JEA 3, p.88.

42 Lloyed A. B.(2010), a Comparison to Ancient Egypt I, Wiley-Blackwell, p.xxxviii

43 Perdu, "Ancient Egyptian Autobiographies," IV :2252

44 Lloyed, a Comparison to Ancient Egypt, p.xxxix

45 AEL III, pp.13-52

46 Otto E.(1954), Die biographischen Inschriften der ägypischen Spätzeit, Leiden, pp.16-19

47 Ibid, pp.23-24; Baines, Society, Morality, and Religious Practice, pp.187-89

48 Otto, Die biographischen Inschriften, pp.53-59

49 AEL III, pp.52-65

50 Lichtheim, Maat in Egyptian autobiographies, pp.191-202.

51 Burkes Sh.(1999), "Death in Qoheleth and Egyptian Biographies of the Late Period", Society of Biblical Literature 170: Atlanta, pp.183-187. 